\title{
EDITORIAL
}

\section{Post-BEPS International Tax Arbitration}

\section{REASONS FOR PROMOTING INTERNATIONAL TAX ARBITRATION}

International Tax Arbitration has recently been encouraged as a result of the Base Erosion and Profit Shifting (BEPS) project, and the domestic and international measures against aggressive tax planning recommended therein, which will probably increase international double taxation. ${ }^{1}$ The need for arbitration is also evidenced by the continuous growth in the number of mutual agreement procedure (MAP) cases. OECD statistics show that MAP transfer pricing cases take on average thirty months to complete (the others take seventeen months) and $45 \%$ of all MAP cases remain without any agreement. $^{2}$

However, there has been limited willingness on the part of states to implement international tax arbitration. Since 2008, Article 25 (5) of the OECD Model Convention has provided for mandatory arbitration if MAP cases remain unresolved, but its impact in bilateral tax treaties has not been significant. ${ }^{3}$ The results under the EU Arbitration Convention, the scope of which was limited to transfer pricing cases have also been frustrating: in the EU Arbitration Convention cases, MAP lasts over fifty months on average. ${ }^{4}$
Tax authorities resist submitting their cases to arbitration, and yet, they show no efficacy in reaching mutual agreements. ${ }^{5}$

The Multilateral Convention (MLI) ${ }^{6}$ and the European Dispute Resolution Directive (DRD) ${ }^{7}$ are the two major instruments providing the legal framework for post-BEPS international tax arbitration. Both establish mandatory binding arbitration, but it is subject to a previous MAP. ${ }^{8}$ Moreover, mandatory binding arbitration in the MLI is not a minimum standard, and only a few countries have signed up for it. ${ }^{\text {? }}$

In the tax community there is broad consensus that international tax arbitration is desirable, necessary even; and that it will bring efficiency. The discussion is about the models and the procedure.

\section{THE TAXPAYER'S ROLE IN ARBITRATION}

Traditionally, in international tax arbitration, taxpayers do not have participation rights, as arbitration is a stateto-state issue. This is arguably more in line with the nature of arbitration and its celerity purposes. ${ }^{10}$ In the framework of the DRD, although taxpayers are not parties to the proceedings, they enjoy significant rights and guarantees, namely the right to submit a complaint, initiating the procedure (Article $3(1)$ ); the right to appeal

\section{Notes}

* I would like to thank Roland Ismer who co-designed with me this Special Issue.

S. Piotrowski, R. Ismer, P. Baker, J. Monsenego, K. Perrou, R. Petruzzi, Ek. Reimer, F. Serrano Antón, L. Stankiewicz, E. Traversa, J. Voje, Towards a Standing Committee Pursuant to Article 10 of the EU Tax Dispute Resolution Directive: A Proposal for Implementation, in this issue.

OECD, Mutual Agreement Procedure Statistics for 2017, http://www.oecd.org/tax/dispute/mutual-agreement-procedure-statistics.htm (accessed 30 May 2019); See the reference also in N. Bravo, Mandatory Binding Arbitration in the BEPS Multilateral Instrument, in this issue; H. de Mooij, Arbitration Institutes: An Issue Overlooked, in this issue.

R. Ismer, Article 25 Mutual Agreement Procedure, in Klaus Vogel on Double Taxation Conventions 136-39 (4th ed., E. Reimer \& A. Rust eds, Wolters Kluwer 2015).

European Commission, EU Joint Transfer Pricing Forum, Overview of Numbers Submitted for Statistics of Pending MAPs Under the Arbitration Convention at the End of 2017, JTPF 007a/2018/EM (Sept. 2018).

See European Commission, supra n. 4

6 OECD, Multilateral Convention to Implement Tax Treaty Related Measures to Prevent Base Erosion and Profit Shifting (OECD Publishing 24 Nov. 2016).

7 EU Dispute Resolution Directive: Council Directive (EU) 2017/1852 of 10 Oct. 2017 on Tax Dispute Resolution Mechanisms in the European Union, OJ L 265/1 (14 Oct. 2017).

8 H. M. Pit, The Changed Landscape of Tax Dispute Resolution Within the EU: Considerations on the Directive on Tax Dispute Resolution Mechanisms Within the European Union, in this issue; Bravo, supra n. 2.

9 See Piotrowski et al., supra n. 1.

$10 \mathrm{~J}$. Avery Jones, Types of Arbitration Procedure, in this issue, para. 3. 
against any arbitrary rejection of the case (Article 5 (3)); the right to request an Advisory Commission (Article 6 (1)); the right to control the adoption of the Rules of Functioning (Article 11 (4)); the right to appear or to be represented before an Advisory Commission or Alternative Dispute Resolution Commission upon consent of the competent authorities of the Member State (Article 13 (2)); the right to appeal in order to obtain the final decision (Article 15 (3)); and the right to apply to enforce implementation of the final decision (Article 15, final indent). ${ }^{11}$

Although these provisions are welcome, it is important to be aware that they bring complexity to and reduce the speed of the system.

\section{EfFICIENCY faIlURES AND COSTS OF ARBITRATION}

International Arbitration under the MLI will probably not overcome previously detected efficiency failures (especially, under Article 25 (5) of the OECD Model Convention). Avery Jones, De Mooij, Piotrowski et al. articles, published below, highlight these inefficiencies. De Mooij proposes the setting up of arbitration institutes or even a permanent court of arbitration. Piotrowski et al, inspired by Article 10 DRD, propose the introduction of an International Standing Committee, which would improve international dispute resolution. They refer to the experience and specialization of arbitrators, to the institutional accumulation of know-how and resources, to guaranteed availability of arbitrators; to transparency; legal certainty for all stakeholders; increased quality and uniformity of decisions; higher standard of taxpayer protection; publication of the decisions; and evolutionary law-making. ${ }^{12}$

In spite of the aforementioned desirability of and the need to encourage international tax arbitration, as the most efficient instrument for eliminating international double taxation; and in spite of the aforementioned advantages that institutionalization of arbitration by some form of international committee would bring, a more in-depth discussion is required in order to clarify what the role to be played by arbitration in the international tax field should be.

This is the case for the relationship between arbitration, some form of standing committee and judicial courts (including the role of taxpayers in the arbitration procedure and their rights), as well as the impact that arbitration has on the judiciary. These aspects need to be assessed, made transparent and explained to all relevant stakeholders: decision makers and users.

There is a relevant precedent illustrating the complexity of the relationship between international arbitration and judicial courts: in the European Union, the issues raised in the Achmea case, which are also discussed in the articles by Monsenego ${ }^{13}$ and Perrou below, reveal the difficulty in understanding the relationship between EU arbitration and the CJEU.

Moreover, the institutionalization of arbitration brings more complexity to it, brings the concept and functioning of arbitration closer to traditional justice, and may accelerate disinvestment in the judicial system. Some economic considerations discussed by Nuno Garoupa, ${ }^{14}$ in the context of domestic tax arbitration, could be taken into account to assess the implications of international tax arbitration. It would be advisable to assess the following: what the implications are for the exercise of justice (fair trial), resulting from the fact that states shape the legal policy and at the same time are parties to arbitration; how can it be ensured that agents representing the states in arbitration are not promoting their own agenda; and what the social costs might be as a result of the so-called fast lane effect, that is, some taxpayers will have access to arbitration, at low cost, with fast results but the state may disinvest in the public system of resolution of conflicts, potentially leading to high social costs. ${ }^{15}$

\section{Concluding REMARKS}

Intertax dedicates this special issue to international tax arbitration. The contributors to this issue share the broad consensus throughout the tax community that international tax arbitration is desirable and necessary. This special issue also includes a policy paper on 'Domestic Tax Arbitration: Some Economic Considerations', inspired by the problems that domestic tax arbitration, as introduced almost ten years ago in Portugal, may raise. The Portuguese example has been followed with curiosity, and is generally seen as having been a success. It did change the dynamics among the different tax players: decisions are fast; relevant issues resulting from arbitration decisions are referred the Constitutional Court; as a result of unfavourable arbitration decisions, the Portuguese legislature has been quick to amend the legislation; and cases are being referred to the Court of Justice of the European Union.

\section{Notes}

See: K. Perrou, Taxpayer Rights and Taxpayer Participation in Procedures Under the Dispute Resolution Directive, in this issue, para. 2.3.3.

Piotrowski et al., supra n. 1

Perrou, supra n. 11, para. 3.3.

N. Garoupa, Domestic Tax Arbitration: Some Economic Considerations, in this issue.

Garoupa, supra n. 14 
All in all, the purpose of this special issue is to encourage a deeper level of debate in the tax community, on the models, procedure and instruments, as well as on the role to be played by arbitration in the international tax field.

Ana Paula Dourado General Editor

Member of the European Association of Tax Law Professors at the EU Platform for Tax Good Governance 